ISSN: 2302-8556

\title{
Pengaruh Reformasi Administrasi Perpajakan dan Tax Amnesty Pada Kepatuhan WPOP Dengan Preferensi Risiko Sebagai Pemoderasi
}

\author{
I Gusti Ayu Putu Erviana Dewi ${ }^{1}$ \\ Ni Putu Sri Harta Mimba ${ }^{2}$ \\ ${ }^{1,2}$ Fakultas Ekonomi dan Bisnis Universitas Udayana (Unud), Bali, Indonesia \\ e-mail: gekevin177@gmail.com
}

\begin{abstract}
ABSTRAK
Tujuan penelitian ini adalah untuk mengetahui pengaruh reformasi administrasi perpajakan dan tax amnesty pada kepatuhan wajib pajak orang pribadi dengan preferensi risiko sebagai pemoderasi (studi di KPP Pratama Badung Utara 2018). Responden dalam penelitian ini sebanyak 100 Wajib Pajak Orang Pribadi yang mengikuti tax amnesty dan terdaftar di KPP Pratama Badung Utara 2018, dihitung menggunakan rumus Slovin dengan metode penentuan sampel accidental sampling. Teknik analisis data penelitian ini menggunakan Moderated Regression Analysis (MRA). Simpulan dari hasil penelitian ini adalah reformasi administrasi perpajakan berpengaruh positif terhadap kepatuhan wajib pajak orang pribadi dan tax amnesty tidak berpengaruh terhadap kepatuhan wajib pajak orang pribadi. Preferensi risiko memperlemah hubungan antara reformasi administrasi perpajakan pada kepatuhan wajib pajak orang pribadi dan memperkuat hubungan antara tax amnesty pada kepatuhan wajib pajak orang.
\end{abstract}

Kata Kunci: Reformasi administrasi perpajakan, tax amnesty, preferensi risiko, kepatuhan WPOP

\begin{abstract}
The purpose of this study was to determine the effect of tax administration reforms and tax amnesty on individual taxpayer compliance with risk preferences as moderating (studies in North Badung North Sumatra 2018 KPP). Respondents in this study as many as 100 Individual Taxpayers who participated in the tax amnesty and registered at the North Badung North KPP 2018, were calculated using the Slovin formula with the method of determining accidental sampling. The data analysis technique of this study uses Moderated Regression Analysis (MRA). The conclusion from the results of this study is that tax administration reform has a positive effect on individual taxpayer compliance and tax amnesty does not affect individual taxpayer compliance. Risk preference weakens the relationship between tax administration reform on individual taxpayer compliance and strengthens the relationship between tax amnesty on people's taxpayer compliance.

Keywords: Tax administration reform, tax amnesty, risk preference, WPOP compliance
\end{abstract}

\section{PENDAHULUAN}

Pajak bukanlah hal yang asing untuk masyarakat Indonesia, dimana pajak merupakan salah satu sumber pendapatan negara. Menurut (Savitri,2015), pajak merupakan sumber penerimaan Negara yang memberikan kontribusi besar dalam 
Anggaran Pendapatan dan Belanja Negara (APBN) dan menjadi andalan untuk membiayai kepentingan pembangunan dan pengeluaran Negara. Pernyataan dari (Marandau et al, 2015) meyakini bahwa perpajakan adalah pusat dari perkembangan ekonomi, sosial dan politik sehingga memiliki peran yang penting dalam suatu negara. Indonesia sebagai Negara berkembang dengan mengandalkan pajak sebagai sumber pendapatan tebesar Negara (Enni \& Musfialdy, 2016). Menurut (Murat, 2014) dominasi pajak sebagai sumber pendapatan merupakan hal yang wajar, mengingat sektor sumber daya alam yang sulit diandalkan, contohnya: minyak bumi, batubara dan tambang lainnya. Menurut (Mohamad dkk.,2015) pajak juga merupakan salah satu jalan bagi pemerintah untuk mewujudkan bangsa dan negara yang mandiri dalam pembangunan, pendidikan, kesehatan dan hal lainnya untuk kepentingan bersama.

Tabel 1.

Informasi Penerimaan Pajak Tahun 2015-2018 (dalam Triliun Rupiah)

\begin{tabular}{lllll}
\hline Keterangan & $\mathbf{2 0 1 5}$ & $\mathbf{2 0 1 6}$ & $\mathbf{2 0 1 7}$ & $\mathbf{2 0 1 8}$ \\
\hline Direktorat Jendral Pajak & Rp 1.055,61 & Rp 1.032 & Rp 1.339\% & $\begin{array}{l}\text { Rp 760,57 } \\
\text { (per } \\
\text { November) }\end{array}$ \\
$\begin{array}{llll}\text { Direktorat Jendral Pajak } \\
\text { Kanwil Bali }\end{array}$ & Rp 6,8 & Rp 9,7 & Rp 8,4 & $\begin{array}{l}\text { Rp 7,7 } \\
\text { (per } \\
\text { November) }\end{array}$ \\
\hline
\end{tabular}

Sumber: www.pajak.go.id, 2018

Penerimaan pajak tahun 2016-2017 mencapai penerimaan tertinggi dikarenakan efek tax amnesty dan penerimaan untuk tahun 2018 belum mencapai penerimaan dari tahun-tahun sebelumnya. Penelitian ini ingin mengetahui lebih lanjut tentang pengaruh tax amnesty pada kepatuhan wajib pajak orang pribadi khususnya tahun 2018. Pemerintah masih belum mampu memenuhi target yang 
ditetapkan tahun 2018, hal ini menjadi tugas untuk pemerintah dalam meningkatkan jumlah penerimaan dengan menggali potensi yang ada. Dalam penelitiannya (Putri, 2015) mengatakan bahwa penerimaan pajak di Indonesia pada umumnya masih di dominasi oleh wajib pajak badan. Menurut (Herbert dkk., 2017) kepatuhan merupakan hal yang mendasar dan penting dalam mensukseskan sistem tersebut. Oleh karena itu, sangat penting apabila kepatuhan wajib pajak dapat timbul dari dalam diri individu secara sukarela.

Kepatuhan wajib pajak dalam melaksanakan kewajiban perpajakaannya merupakan salah satu kunci dalam mendorong peningkatan penerimaan Negara dari sektor pajak. Kepatuhan merupakan salah satu perilaku seseorang yang taat dan bersifat patuh dan kepatuhan wajib pajak terjadi saat wajib pajak tersebut mentaati hukum perpajakan (Mahangila, 2017). Menurut (Hatta et al.,2016) kepatuhan wajib pajak dipengaruhi oleh beberapa faktor yaitu faktor internal dan eksternal dari wajib pajak itu sendiri. Menurut (Herbert dkk., 2017) untuk mengetahui faktor-faktor yang dapat mempengaruhi perilaku kepatuhan digunakan pendekatan teori atribusi yaitu tentang menafsirkan, menjelaskan, dan meramal perilaku sesorang.

Pemerintah memerlukan usaha dan strategi khusus untuk mencapai target dari penerimaan pajak yang telah ditetapkan. Pencapaian pada Agustus 2018 tidak terlepas dari usaha Pemerintah dalam mencari potensi pajak yang ada, salah satunya langkah pemerintah melalui DJP untuk melakukan reformasi di bidang perpajakan (tax reform). Reformasi perpajakan yang dilakukan mencakup bidang 
kebijakan dan administrasi perpajakan. Pada bidang administrasi perpajakan dilakukan reformasi dengan menerapkan program modernisasi administrasi perpajakan. Dalam penelitian (Sugi dan Lely, 2017) modernisasi administrasi perpajakan mencakup 4 bidang, yaitu: (1) restrukturisasi organisasi; (2) perbaikan proses bisnis melalui optimalisasi penggunaan teknologi informasi dan komunikasi; (3) perbaikan sistem manajemen sumber daya manusia; dan (4) pelaksanaan good governance. Dilaksanakannya reformasi administrasi tentunya memiliki suatu tujuan, menurut DJP (2012) tujuan utama reformasi administrasi perpajakan yaitu meningkatkan kepatuhan sukarela wajib pajak, meningkatkan kepercayaan masyarakat, dan meningkatkan produktivitas dan integritas aparat pajak. Menurut (Ariesta \& Latifah, 2017) dengan reformasi administrasi perpajakan, didukung dengan Sumber Daya Manusia (SDM) yang profesional dan berkualitas serta mempunyai kode etik kerja diharapkan akan tercipta prinsip good governance yang dilandasi transparansi, akuntabel, responsif, independen dan adil. Reformasi administrasi perpajakan juga berkembang mengikuti kemajuan teknologi dengan pelayanan yang berbasis e-System seperti e-SPT, e-Filling, ePayment dan e-Registration yang diharapkan dapat meningkatkan kontrol yang lebih efektif.

Usaha pemerintah dalam meningkatkan kepatuhan wajib pajak tidak hanya terpaku pada satu usaha, pemerintah menciptakan usaha lain yang cenderung lebih mengajak wajib pajak untuk melaksanakan kewajiban perpajakannya dengan instrumen pengapusan sanksi pajak, yaitu reinventing policy pada tahun 2015 . Hal 
ini diatur dalam Pasal 37A Undang-Undang Ketentuan Umum dan Tata Cara Perpajakan (Undang-Undang Nomor 28 Tahun 2007). Reinventing policy hanya berlaku sampai tahun 2016 dan kemudian pemerintah menerbitkan instrument baru.

Tax amnesty adalah instrument pemerintah yang selanjutnya diharapkan dapat meningkatkan kepatuhan wajib pajak. Menurut (Sari \& Nuswantara, 2017) tax amnesty adalah pengapusan pajak yang seharusnya terutang, tidak dikenai sanksi administrasi perpajakan dan sanksi pidana di bidang perpajakan dengan mengungkapkan harta dan membayar uang tebusan dan pendapat lain dari (Nar,2015) tax amnesty memungkinkan wajib pajak untuk membayar hutang pajak yang belum terbayar tanpa menimbulkan tambahan biaya keterlambatan atau hukuman lain. Tax amnesty diatur dalam Undang-Undang Republik Indonesia No.11 Tahun 2016 tentang Pengampunan Pajak. Menurut (Waluyo, 2017) tax amnesty ini merupakan upaya pemerintah untuk menarik dana masyarakat yang selama ini membayar pajak di negara lain. Walaupun demikian, menurut (Rahayu, 2017) kebijakan ini masih perlu diselaraskan dengan instansi penegak hukum lain. Hal ini terkait dengan pihak-pihak yang dinilai pantas menerima pengampunan pajak.

Tabel 2.

Jumlah WPOP yang mengikuti Tax Amnesty dan Laporan Penerimaan Tax Amnesty Tahap 1 dan 2 tahun 2017

\begin{tabular}{lcc}
\hline Keterangan & $\begin{array}{c}\text { Wajib Pajak yang Mengikuti } \\
\text { Tax Amnesty }\end{array}$ & Pendapatan Tax Amnesty (dalam rupiah) \\
\hline Tahap 1 & 1.740 & $57,860,570,594$ \\
Tahap 2 & & $25,424,892,204$ \\
\hline Sumber: Data diolah, 2018 &
\end{tabular}


Dalam melakukan pembayaran pajak, wajib pajak harus mempertimbangkan risiko-risiko apa yang akan dihadapinya (Andriyani, 2016). Risiko yang menjadi pertimbangan adalah risiko kesehatan, risiko sosial, risiko keuangan, risiko pekerjaan, dan risiko keselamatan. Menurut Stikin \& Pablo 1992 dalam (Gärtner et al., 2017) preferensi risiko yaitu salah satu karakteristik individu dimana akan mempengaruhi perilakunya. Wajib pajak akan mempertimbangkan tindakannya karena menghadapi sebuah risiko, terutama dalam hal kepatuhan membayar pajak yang dapat berdampak secara langsung pada risiko keuangannya (Frey \& Torgler, 2007). Keputusan wajib pajak individu dapat dipengaruhi oleh sikap mereka terhadap risiko (Aryobimo, 2012). Wajib pajak dapat memilih apakah memutuskan untuk menghadapi atau menghindari risiko tersebut. Jadi, alasan dari pemilihan preferensi risiko sebagai variabel moderasi adalah karena preferensi risiko merupakan faktor dari dalam diri wajib pajak itu sendiri dalam menghadapi risiko-risiko dalam hidupnya yang dapat mempengaruhi keputusan yang akan diambil dari wajib pajak.

Penelitian yang dilakukan oleh (Adhistyastuti dkk., 2016) menyimpulkan bahwa reformasi administrasi perpajakan tidak berpengaruh terhadap kepatuhan wajib pajak orang pribadi. Namun, penelitian yang dilakukan oleh (Sugi \& Lely, 2017) menyimpulkan bahwa reformasi administrasi perpajakan berpengaruh positif terhadap kepatuhan wajib pajak orang pribadi. Hasil penelitian yang dilakukan oleh (Lestari dkk., 2013) menyebutkan bahwa reformasi administrasi perpajakan berpengaruh $42,6 \%$ terhadap kepatuhan wajib pajak orang pribadi. 
Penelitian yang dilakukan oleh (Wirawan \& Noviari, 2017) menyatakan bahwa tax amnesty berpengaruh positif terhadap kepatuhan wajib pajak orang pribadi. Berdasarkan penelitian (Ariesta \& Latifah, 2017) menyatakan bahwa tax amnesty berpengaruh 5,90 \% terhadap kepatuhan wajib pajak, dimana angka tersebut cukup rendah dibanding kesadaran wajib pajak yang mencapai 9,36\%.

Fokus riset ini adalam mencoba menambahkan variabel yang dianggap dapat mempengaruhi kepatuhan wajib pajak orang pribadi dalam melaksanakan kewajiban perpajakannya. Variabel yang ditambahkan tersebut adalah reformasi administrasi perpajakan pada kepatuhan wajib pajak orang pribadi. Dari sinilah yang membedakan penelitian sekarang dengan penelitian sebelumnya (Ismawati, 2017) variabel independen yang digunakan adalah pemahaman peraturan perpajakan, kualitas pelayanan fiskus, sanksi pajak dan tax amnesty dengan preferensi risiko sebagai variabel pemoderasi. Penelitian ini mengadopsi variabel independen tax amnesty dan menambahkan variabel reformasi administrasi perpajakan yang dianggap lebih terkini dan sesuai dengan kemajuan teknologi.

KPP Pratama Badung Utara adalah salah satu kantor administrasi pajak yang terdapat di Kabupaten Badung. Alasan peneliti memilih KPP ini sebagai lokasi penelitian dikarenakan tingkat kepatuhan wajib pajak orang pribadinya masih rendah. Secara jelas dapat dilihat pada Tabel 3 berikut ini.

Tabel 3.

Rasio Kepatuhan Wajib Pajak Orang Pribadi (WPOP) di KPP Pratama Badung Utara pada Tahun 2013-2017

\begin{tabular}{lccccc}
\hline 2013 & 2014 & 2015 & 2016 & $\begin{array}{c}2017 \\
\text { (perakhir } \\
\text { Oktober) }\end{array}$ \\
\hline WPOP & 49.205 & 53.124 & 57.060 & 60.528 & 63.664
\end{tabular}




\begin{tabular}{|c|c|c|c|c|c|}
\hline \multicolumn{6}{|l|}{ Terdaftar } \\
\hline $\begin{array}{l}\text { SPT WPOP } \\
\text { Masuk }\end{array}$ & 23.714 & 24.515 & 25.001 & 26.590 & 26.182 \\
\hline $\begin{array}{l}\text { Rasio } \\
\text { Kepatuhan* }\end{array}$ & $48,19 \%$ & $46,15 \%$ & $43,82 \%$ & $43,39 \%$ & $41,13 \%$ \\
\hline
\end{tabular}

Berdasarkan Tabel 3 di atas, terlihat secara garis besar terjadi penurunan tingkat kepatuhan wajib pajak orang pribadi pada KPP Pratama Badung Utara. Hal tersebut menjadi alasan bagi peneliti untuk memilih KPP Pratama Badung Utara sebagai tempat penelitian.

Berdasarkan teori atribusi, reformasi administrasi perpajakan merupakan penyebab eksternal yang dapat memengaruhi kepatuhan wajib pajak orang pribadi. Reformasi administrasi perpajakan bertujuan untuk menerapkan good governance dan pelayanan yang prima kepada masyarakat (Ariesta \& Latifah, 2017). Pelaksanaan modernisasi administrasi perpajakan mencakup 4 bidang, yaitu : (1) restrukturisasi organisasi; (2) perbaikan proses bisnis melalui optimalisasi penggunaan teknologi informasi dan komunikasi; (3) perbaikan sistem manajemen sumber daya manusia; dan (4) pelaksanaan good governance.

Hasil penelitian dari (Sayekti \& Wijayanti, 2018) dan (Sugi \& Lely, 2017) membuktikan bahwa ada pengaruh positif antara reformasi administrasi perpajakan dengan kepatuhan wajib pajak orang pribadi. Berdasarkan telaah teori dan hasil-hasil penelitian terdahulu, maka dirumuskan hipotesis sebagai berikut:

$\mathrm{H}_{1}$ : Reformasi administrasi perpajakan berpengaruh positif pada kepatuhan wajib pajak orang pribadi.

Berdasarkan teori atribusi tax amnesty merupakan penyebab eksternal yang dapat memengaruhi kepatuhan wajib pajak orang pribadi. Tax amnesty atau 
pengampunan pajak merupakan sebuah kesempatan berbatas waktu bagi kelompok wajib pajak tertentu untuk membayar pajak yang berkaitan dengan masa pajak sebelumnya tanpa penuntutan pidana (Ibrahim et al, 2017). Penerapan tax amnesty dalam perundang-undangan perpajakan di Indonesia adalah untuk meningkatkan kepatuhan wajib pajak (Mahestyanti et al, 2018). Tax amnesty yang diimplementasikan oleh pemerintah ini berjalan pada tahun 2016 hingga tahun 2017 yang diawali dengan sosialisasi dari jajaran tertinggi pemerintah yaitu Presiden, hingga pelaksana terendah di Kantor Pelayanan Pajak. Diharapkan dengan adanya sosialisasi tersebut wajib pajak memiliki pengetahuan yang cukup mengenai perpajakan sehingga menjadi pertimbangan dalam melaksanakan kewajiban perpajakannya

Hasil penelitian dari (Rorong dkk., 2017) dan (Husnurrosyidah, 2016) membuktikan bahwa ada pengaruh positif antara tax amnesty dengan kepatuhan wajib pajak orang pribadi. Berdasarkan telaah teori dan hasil-hasil penelitian terdahulu, maka dirumuskan hipotesis sebagai berikut:

$\mathrm{H}_{2}$ : Tax amnesty berpengaruh positifpada kepatuhan wajib pajak orang pribadi.

Reformasi administrasi perpajakan memiliki tujuan utama yaitu memberikan pelayanan kepada masyarakat dalam memenuhi kewajiban perpajakannya. reformasi dalam bidang perpajakan dilakukan secara bertahap, tahap pertama tahun 2002-2009. Pada tahun tersebut dilakukan dua perubahan mendasar yaitu pada bidang administrasi dan kebijakan. Tahap kedua dilakukan tahun 2009-2012 yang difokuskan pada pengembangan sumber daya manusia dan 
penggunaan teknologi informasi dalam administrasi perpajakan. Hal tersebut diperkuat dengan hasil penelitian oleh (Novelina, 2017) yang menyatakan bahwa reformasi administrasi perpajakan berpengaruh terhadap kepatuhan wajib pajak.

Dalam penelitian ini preferensi risiko sebagai variabel moderasi, maka secara operasional preferensi risiko merupakan peluang yang akan dipertimbangkan oleh wajib pajak yang menjadi propritas lainnya dari berbagai pilihan yang tersedia (Aryobimo, 2012). Dasar teori yang digunakan preferensi risiko dalam mempengaruhi keputusan wajib pajak adalah teori prospek. Menurut (Togler, 2003) dalam (Julianti, 2014) menyampaikan bahwa keputusan seorang wajib pajak dapat dipengaruhi oleh sikap mereka terhadap risiko. Menurut penelitian (Aryobimo,2012) ketika kepatuhan pajak memiliki hubungan kuat dengan preferensi risiko maka tingkat kepatuhan wajib pajak akan rendah artinya wajib pajak memiliki berbagai risiko yang tinggi akan dapat menurunkan tingkat kepatuhan wajib pajak. Ketika seorang wajib pajak mempunyai tingkat preferensi risiko yang tinggi baik risiko keuangan, risiko kesehatan dan risiko pekerjaan akan mempengaruhi keputusan wajib pajak tersebut. Ketika wajib pajak tersebut memiliki masalah keuangan seperti mengalami kebangkrutan, kesehatan seperti penyakit kronis, gangguan jiwa, dan masalah pekerjaan seperti pekerjaan yang tidak tetap dan terancam PHK, akan membuat wajib pajak enggan dalam mematuhi kewajiban perpajakannya. Jadi hal tersebut menjadi pertimbangan walaupun dengan adanya reformasi administrasi perpajakan yang bertujuan untuk mempermudah wajib pajak dalam memenuhi kewajiban perpajakannya. 
Oleh karena itu, ketika seorang wajib pajak mempunyai tingkat preferensi risiko yang tinggi maka hubungan antara reformasi administrasi perpajakan buruk dan kepatuhan wajib pajak lemah atau wajib pajak tersebut cenderung lebih tidak taat dalam membayar pajak, sedangkan apabila seorang wajib pajak memiliki tingkat risiko yang rendah maka hubungan antara reformasi administrasi perpajakan tinggi maka wajib pajak tersebut cenderung untuk lebih taat dalam membayar pajak sehingga kepatuhan wajib pajak meningkat.

Penelitian oleh (Julianti, 2014) mengemukakan bahwa preferensi risiko sebagai variabel moderasi memperlemah hubungan antara persepsi wajib pajak tentang kualitas pelayanan pajak dengan kepatuhan wajib pajak. Penelitian oleh (Aziz dkk., 2014) mengemukakan bahwa preferensi risiko sebagai variabel moderasi, memperlemah hubungan antara peraturan tentang wajik pajak dengan kepatuhan wajib pajak.

Berdasarkan uraian di atas dapat disimpulkan preferensi risiko sebagai variabel moderasi dapat memperkuat atau memperlemah hubungan antara variabel independen dengan variabel dependen. Berdasarkan telaah teori dan hasil-hasil penelitian terdahulu, maka dirumuskan hipotesis sebagai berikut:

$\mathrm{H}_{3}$ : Preferensi risiko memperlemah hubungan antara reformasi administrasi perpajakan pada kepatuhan wajib pajak orang pribadi.

Pengampunan pajak atau tax amnesty adalah suatu kesempatan dengan batas waktu bagi kelompok wajib pajak tertentu untuk membayar pajak dengan jumlah tertentu sebagai pengampunan atas kewajiban membayar pajak yang berkaitan dengan masa pajak sebelumnya tanpa penuntutan pidana perpajakan 
(Nurlaela et al., 2017). Dalam penelitian oleh (Rahayu, 2017) mengemukakan bahwa tax amnesty berpengaruh terhadap kepatuhan wajib pajak.

Menurut Togler (2003) dalam (Andriyani, 2016) menyatakan bahwa keputusan wajib pajak dapat dipengaruhi oleh perilakunya terhadap risiko yang dihadapi. Teori yang mendasari keterkaitan preferensi risiko dengan kepatuhan wajib pajak orang pribadi adalah teori prospek. Keterkaitannya dengan teori prospek yaitu ketika wajib pajak mempunyai tingkat risiko yang tinggi maka akan mempengaruhi kepatuhan wajib pajak. Menurut penelitian (Aryobimo,2102) ketika kepatuhan pajak memiliki hubungan kuat dengan preferensi risiko maka tingkat kepatuhan wajib pajak akan rendah artinya wajib pajak memiliki berbagai risiko yang tinggi akan dapat menurunkan tingkat kepatuhan wajib pajak. Dalam hal ini lebih mengarah ke risiko keuangan seperti memiliki investasi yang berisiko, berwirausaha dan mengalami kebangkrutan yang menjadi pertimbangan wajib pajak dalam mengikuti tax amnesty. Namun, menurut teori prospek, apabila seseorang wajib pajak memiliki risiko yang tinggi maka wajib pajak tersebut belum tentu akan tidak membayar kewajiban perpajakannya. karena apabila wajib pajak memiliki sifat risk seeking artinya walaupun wajib pajak memiliki risiko yang tinggi maka tidak akan mempengaruhi wajib pajak tersebut untuk membayar pajak, sedangkan wajib pajak yang memiliki sifat risk aversion apabila wajib pajak tersebut memiliki risiko yang rendah maka wajib pajak justru akan menghindari kewajiban perpajakannya. 
Oleh karena itu, ketika seorang wajib pajak mempunyai tingkat preferensi risiko yang tinggi yang lebih mengarah pada risiko keuangan, maka semakin lama masa berlaku tax amnesty dan dengan adanya preferensi risiko dapat mengakibatkan wajib pajak semakin tinggi dalam melaksanakan kewajiban perpajakannya. Terlebih lagi tax amnesty memiliki sanksi administrasi perpajakan berupa kenaikan sebesar $200 \%$ bagi wajib pajak yang melanggar sesuai UndangUndang Nomor 11 tahun 2016.

Penelitian oleh (Alabede et al., 2011) bahwa perefernsi risiko berpengaruh positif terhadap kepatuhan wajib pajak orang pribadi. Penelitian oleh (Ismawati, 2017) mengemukakan bahwa preferensi risiko sebagai variabel moderasi memperkuat hubungan antara tax amnesty dengan kepatuhan wajib pajak. Dari uraian di atas dapat diambil kesimpulan bahwa variabel preferensi risiko sebagai variabel moderasi dapat memperkuat atau memperlemah hubungan antara variabel independen dengan variabel dependen. Berdasarkan telaah teori dan hasil-hasil penelitian terdahulu, maka dirumuskan hipotesis sebagai berikut:

$\mathrm{H}_{4}$ : Preferensi risiko memperkuat hubungan antara tax amnesty pada kepatuhan wajib pajak orang pribadi.

\section{METODE PENELITIAN}

Penelitian ini mengambil lokasi di KPP Pratama Badung Utara yang merupakan salah satu kantor administrasi perpajakan yang ada di Kabupaten Badung. KPP Pratama Badung Utara beralamat di Jl.Ahmad Yani No.100, Dauh Puri Kaja, Denpasar Utara, Kota Denpasar dengan kode pos 80231. 
Populasi dalam penelitian ini adalah wajib pajak orang pribadi pada Kantor Pelayanan Pajak Pratama Badung Utara yang mengikuti tax amnestyyang berjumlah 1.740 orang. Jumlah sampel dalam penelitian ini diketahui dengan menggunakan rumus Slovin yaitu:

$n=\frac{N}{1+N \cdot e^{2}}=\frac{1.740}{1+1.740(0,1)^{2}}=100($ dibulatkan $)$

Keterangan:

$\mathrm{n}=$ Jumlah sampel

$\mathrm{N}=$ Jumlah populasi

$\mathrm{e}=$ Tingkat kesalahan yang ditoleransi (peneliti menggunakan sebesar 10\%)

MRA (Moderated Regression Analyisis) merupakan aplikasi dari linier berganda dimana dalam persamaan regresinya mengandung usur interaksi (perkalian dua atau lebih variabel independen). MRA merupakan metode analisis data yang digunakan dalam penelitian ini untuk mengukur pengaruh variabel independen yaitu preferensi risiko terhadap reformasi administrasi perpajakan dan tax amnesty pada kepatuhan wajib pajak. Rumus yang digunakan sebagai berikut:

$Y=\alpha+\beta_{1} X_{1}+\beta_{2} X_{2}+\beta_{3} Z+\beta_{4}\left(X_{1} Z\right)+\beta_{5}\left(X_{2} Z\right)+e$

Keterangan:

Y $\quad=$ Kepatuhan Wajib Pajak

$\alpha \quad=$ Konstanta

$\beta_{1,2,3,4,5}=$ Koefisien regresi

$\mathrm{X}_{1} \quad=$ Reformasi administrasi perpajakan

$\mathrm{X}_{2} \quad=$ Tax Amnesty

$\mathrm{Z} \quad=$ Preferensi Risiko

$\mathrm{X}_{1} \mathrm{Z} \quad=$ Interaksi antara reformasi administrasi perpajakan dengan preferensi risiko wajib pajak

$\mathrm{X}_{2} \mathrm{Z} \quad=$ Interaksi antara tax amnestydengan preferensi risiko wajib pajak

$\mathrm{e}=$ Komponen error 


\section{HASIL DAN PENELITIAN}

Adapun pada penelitian ini variabel yang digunakan yakni reformasi administrasi perpajakan, tax amnesty, preferensi risiko dan kepatuhan wajib pajak orang pribadi. Statistik deksriptif pada penelitian ini ditunjukkan pada Tabel 4.

Tabel 4.

Statistik Deskriptif

\begin{tabular}{lccccc}
\hline \multicolumn{1}{c}{ Variabel } & N & Min. & Max. & Mean & Std. Deviation \\
\hline Reformasi Administrasi & 100 & 10,00 & 39,56 & 28,8127 & 8,56017 \\
Perpajakan $\left(\mathrm{X}_{1}\right)$ & 100 & 5,00 & 18,95 & 14,3079 & 4,47007 \\
Tax Amnesty $\left(\mathrm{X}_{2}\right)$ & 100 & 11,00 & 41,34 & 33,5450 & 9,73061 \\
$\begin{array}{l}\text { Preferensi Risiko (Z) } \\
\text { Kepatuhan Wajib Pajak Orang }\end{array}$ & 100 & 7,00 & 28,20 & 20,4785 & 6,33861 \\
$\begin{array}{l}\text { Pribadi (Y) } \\
\text { Reformasi Administrasi }\end{array}$ & & & & \\
$\begin{array}{l}\text { Perpajakan (X1) * Preferensi } \\
\text { Risiko (Z) }\end{array}$ & 100 & 110,00 & 1635,78 & 1022,0486 & 459,17805 \\
$\begin{array}{l}\text { Tax Amnesty (X2)* Preferensi } \\
\text { Risiko (Z) }\end{array}$ & 100 & 55,00 & 783,45 & 510,3612 & 235,70727 \\
\hline $\begin{array}{l}\text { Sumber: Data } \\
\text { Nion }\end{array}$ & & & & &
\end{tabular}

Sumber: Data diolah, 2018

Berdasarkan Tabel 4 di atas, hasil uji statistik deskriptif dapat diuraikan dengan penjelasan sebagai berikut.

Berdasarkan Tabel 4 di atas diperoleh nilai terendah (minimum) untuk variabel reformasi administrasi perpajakan sebesar 10,00 dan nilai tertinggi (maximum) sebesar 39,56 hal ini mengidentifikasikan bahwa nilai yang diberikan responden pada variabel reformasi administrasi perpajakan 10 poin pertanyaan pada kuesioner yakni 10,00 sedangkan nilai tertinggi sebesar 39,56. Sedangkan nilai rata-rata (mean) yang diukur dengan menggunakan 10 poin pertanyaan sebesar 28,8127 dengan nilai standar deviasi sebesar 8,56017. Ini berarti bahwa jumlah nilai pada variabel reformasi administrasi perpajakan yang diberikan responden dibagi total reponden menunjukkan nilai rata-rata sebesar 28,8127. 
Berdasarkan Tabel 4 di atas diperoleh nilai terendah (minimum) untuk variabel tax amnesty yakni 5,00 dan nilai tertinggi (maximum) yakni sebesar 18,95, hal ini mengidentifikasikan bahwa nilai yang diberikan responden pada variabel tax amnesty melalui 5 poin pertanyaan pada kuesioner yakni sebesar 5,00 sedangkan nilai tertinggi sebesar 18,95. Nilai rata-rata (mean) yang diukur dengan menggunakan 4 poin pertanyaan sebesar 14,3079 dengan nilai standar deviasi sebesar 4,47007. Ini berarti bahwa jumlah nilai pada variabel tax amnesty yang diberikan responden dibagi total responden menunjukkan nilai rata-rata sebesar 14,3079 .

Berdasarkan Tabel 4 di atas diperoleh nilai terendah (minimum) untuk variabel preferensi risiko yakni sebesar 11,00 dan nilai tertinggi (maximum) yakni sebesar 41,34, hal ini mengidentifikasikan bahwa nilai yang diberikan responden pada variabel preferensi risiko melalui 11 poin pertayaan pada kuesioner yakni sebesar 11,00 sedangkan nilai tertinggi 41,34. Nilai rata-rata (mean) yang diukur dengan menggunakan 11 poin pertanyaan sebesar 33,5450 dengan nilai standar deviasi sebesar 9,73061. Ini berarti bahwa jumlah nilai pada variabel preferensi risiko yang diberikan responden dibagi total responden menunjukkan nilai ratarata sebesar 33,5450 yang menunjukkan bahwa tipe responden di KPP Pratama Badung Utara 2018 adalah risk seeking dimana hal ini berarti bahwa responden cenderung berani mengambil risiko, risiko-risiko yang akan dialami wajib pajak tidak akan mempengaruhi kepatuhan perpajakannya. 
Berdasarkan Tabel 4 di atas diperoleh nilai terendah (minimum) untuk variabel kepatuhan wajib pajak orang pribadi yakni sebesar 7,00 dan nilai tertinggi (maximum) yakni sebesar 28,20 hal ini mengidentifikasikan bahwa nilai yang diberikan responden pada variabel kepatuhan wajib pajak orang pribadi melalui 7 poin pertanyaan pada kuesioner yakni sebesar 7,00 sedangkan nilai tertinggi sebesar 28,20. Nilai rata-rata (mean) yang diukur dengan menggunakan 7 poin pertanyaan sebesar 20,4785 dengan standar deviasi 6,33861. Ini berarti bahwa jumlah nilai pada variabel kepatuhan wajib pajak orang pribadi yang diberikan responden dibagi total responden menunjukkan nilai rata-rata sebesar 20,4785 .

Pada penelitian ini pengujian hipotesis dilakukan dengan analisis regresi moderasi yang dihitung dengan menggunakan program SPSS melalui uji interaksi. Analisis regresi moderasi berguna untuk mengetahui pengaruh reformasi administrasi perpajakan dan tax amnesty pada kepatuhan wajib pajak orang pribadi dan preferensi risiko pada hubungan antara reformasi administrasi perpajakan dan tax amnesty pada kepatuhan wajib pajak orang pribadi. Berikut hasil analisis regresi moderasi yang disajikan pada Tabel 5.

Tabel 5.

Hasil Regresi Moderasi

\begin{tabular}{|c|c|c|c|c|c|}
\hline \multirow[t]{2}{*}{ Model } & \multicolumn{2}{|c|}{ Unstandardized Coefficients } & \multirow{2}{*}{$\begin{array}{c}\text { Standardized } \\
\text { Coefficients } \\
\text { Beta } \\
\end{array}$} & \multirow[t]{2}{*}{$\mathrm{T}$} & \multirow[t]{2}{*}{ Sig. } \\
\hline & B & Std. Error & & & \\
\hline (Constant) & 0,940 & 3,656 & & 0,257 & 0,798 \\
\hline $\mathrm{X} 1$ & 0,593 & 0,151 & 0,800 & 3,927 & 0,000 \\
\hline $\mathrm{X} 2$ & $-0,146$ & 0,324 & $-0,103$ & $-0,450$ & 0,654 \\
\hline $\mathrm{Z}$ & 0,145 & 0,130 & 0,223 & 1,115 & 0,268 \\
\hline X1_Z & $-0,013$ & 0,005 & $-0,909$ & $-2,545$ & 0,013 \\
\hline $\mathrm{X} 2 \_\mathrm{Z}$ & 0,025 & 0,010 & 0,911 & 2,408 & 0,018 \\
\hline
\end{tabular}


$F_{\text {hitung }}: 38,119$

Sig. F $_{\text {hitung }}: 0,000$

Sumber: Data diolah, 2018

Berdasarkan Tabel 5 dapat disusun persamaan regresi sebagai berikut: $Y=0,940+0,593 X_{1}-0,146 X_{2}+0,145 Z-0,013 X_{1} Z+0,025 X_{2} Z+e$

Nilai konstanta $(\alpha)$ sebesar 0,940 . Nilai konstanta tersebut bernilai positif memiliki arti bahwa dengan adanya reformasi administrasi perpajakan $\left(\mathrm{X}_{1}\right)$, tax amnesty $\left(\mathrm{X}_{2}\right)$, preferensi risiko $(\mathrm{Z})$, interaksi antara reformasi administrasi perpajakan dengan preferensi risiko $\left(\mathrm{X}_{1} \mathrm{Z}\right)$ dan interaksi antara tax amnesty dengan preferensi risiko $\left(\mathrm{X}_{2} \_\mathrm{Z}\right)$, maka kepatuhan wajib pajak orang pribadi ( $\mathrm{Y}$ ) akan meningkat sebesar 0,940 satuan.

Nilai koefisien $\beta_{1}$ pada variabel reformasi administrasi perpajakan sebesar 0,593 memiliki arti jika variabel lainnya konstan sementara reformasi administrasi perpajakan $\left(\mathrm{X}_{1}\right)$ naik sebesar 1 satuan, maka kepatuhan wajib pajak orang pribadi (Y) akan meningkat sebesar 0,593 satuan.

Nilai koefisien $\beta_{2}$ pada variabel tax amnesty sebesar -0,146 memiliki arti jika variabel lainnya konstan sementara tax amnesty $\left(\mathrm{X}_{2}\right)$ naik sebesar 1 satuan, maka kepatuhan wajib pajak orang pribadi (Y) akan menurun sebesar 0,146 satuan.

Nilai koefisien interaksi reformasi administrasi perpajakan dengan preferensi risiko sebesar $-0,013$ memiliki arti apabila variabel lainnya konstan, sementara variabel reformasi administrasi perpajakan dengan preferensi risiko naik satu satuan maka kepatuhan wajib pajak akan menurun 0,013 satuan.

Nilai koefisien interaksi tax amnesty dengan preferensi risiko sebesar 0,025 memiliki arti apabila variabel lainnya konstan, sementara variabel interaksi tax 
amnesty dengan preferensi risiko naik satu satuan maka kepatuhan wajib pajak orang pribadi menurun 0,025 satuan.

Berdasarkan Tabel 5 terlihat bahwa koefisien determinasi (Adjusted $\mathrm{R}^{2}$ ) sebesar 0,652 . Nilai adjusted $\mathrm{R}^{2}$ sebesar 0,652 memiliki arti bahwa $65,2 \%$ variasi kepatuhan wajib pajak orang pribadi mampu dijelaskan oleh variabel reformasi administrasi perpajakan dan tax amnesty serta variabel preferensi risiko sebagai pemoderasi. Sisanya sebesar 34,8\% dijelaskan oleh variabel lainnya diluar model.

Uji F digunakan untuk mengetahui kelayakan model regresi sebagai alat untuk dianalisis yang menguji pengaruh variabel independen secara serempak pada variabel dependen. Hasil uji kelayakan model (uji F) regresi moderasi dalam penelitian ini disajikan dalam Tabel 6.

Tabel 6.

Hasil Uji Kelayakan Model (Uji F) Regresi Moderasi

\begin{tabular}{|c|c|c|c|c|c|c|}
\hline \multicolumn{2}{|c|}{ Model } & Sum of Squares & df & Mean Square & $\mathbf{F}$ & Sig. \\
\hline 1 & Regression & 2663,836 & 5 & 532,767 & 38,119 & $0,000^{\mathrm{b}}$ \\
\hline & Residual & 1313,785 & 94 & 13,976 & & \\
\hline & Total & 3977,621 & 99 & & & \\
\hline
\end{tabular}

Sumber: Data diolah, 2018

Berdasarkan Tabel 6 terlihat bahwa signifikan $\mathrm{F}$ atau $\mathrm{P}$ value sebesar 0,000 yang lebih kecil dari 0,05. Nilai signifikan $F$ atau $P$ value sebesar 0,000 yang lebih kecil dari 0,05 memiliki arti bahwa seluruh variabel mampu memprediksi atau menjelaskan kepatuhan wajib pajak orang pribadi dan model regresi yang digunakan dianggap layak uji.

Pada hipotesis pertama $\left(\mathrm{H}_{1}\right)$ dikemukakan bahwa reformasi administrasi perpajakan berpengaruh positif pada kepatuhan wajib pajak orang pribadi. Untuk menguji pengaruh reformasi administrasi perpajakan pada kepatuhan wajib pajak 
orang pribadi dilakukan dengan melihat hasil uji statistik dengan SPSS pada Tabel 5 menunjukkan bahwa nilai tingkat signifikansi t sebesar 0,000, lebih kecil dari tingkat signifikansi 5\% $(0,05)$ dengan koefisien regresi sebesar 0,593, sehingga dapat disimpulkan bahwa $\mathrm{H}_{1}$ diterima.

Pada hipotesis kedua $\left(\mathrm{H}_{2}\right)$ dikemukakan bahwa tax amnesty berpengaruh positif pada kepatuhan wajib pajak orang pribadi. Untuk menguji pengaruh tax amnesty pada kepatuhan wajib pajak orang pribadi dilakukan dengan melihat hasil uji statistik dengan SPSS pada Tabel 5 Hasil dalam Tabel 5 menunjukkan bahwa tingkat signifikansi t sebesar 0,654, lebih besar dari tingkat signifikansi 5 persen $(0,05)$ dengan koefisien regresi sebesar $-0,146$, sehingga dapat disimpulkan $\mathrm{H}_{2}$ ditolak.

Pada hipotesis ketiga $\left(\mathrm{H}_{3}\right)$ dikemukakan bahwa preferensi risiko memperlemah hubungan reformasi administrasi perpajakan pada kepatuhan wajib pajak orang pribadi. Untuk menguji pengaruh preferensi risiko memperlemah hubungan reformasi administrasi perpajakan pada kepatuhan wajib pajak orang pribadi, dilakukan dengan melihat hasil uji statistik dengan SPSS pada Tabel 45. Hasil dalam Tabel 5 menunjukkan bahwa nilai tingkat signifikansi t sebesar 0,013, lebih kecil dari tingkat signifikansi 5\% (0,05) dengan koefisien regresi sebesar (-0,013), sehingga dapat disimpulkan bahwa $\mathrm{H}_{3}$ diterima.

Pada hipotesis keempat $\left(\mathrm{H}_{4}\right)$ dikemukakan bahwa preferensi risiko memperkuat hubungan tax amnesty pada kepatuhan wajib pajak orang pribadi. Untuk menguji pengaruh preferensi risiko memperkuat hubungan tax amnesty 
pada kepatuhan wajib pajak orang pribadi, dilakukan dengan melihat hasil uji statistik dengan SPSS pada Tabel 5. Hasil dalam Tabel 5 menunjukkan bahwa nilai tingkat signifikansi t sebesar 0,018, lebih kecil dari tingkat signifikansi 5\% $(0,05)$ dengan koefisien regresi sebesar 0,025 , sehingga dapat disimpulkan bahwa $\mathrm{H}_{4}$ diterima.

Hipotesis $\left(\mathrm{H}_{1}\right)$ menyatakan bahwa reformasi administrasi perpajakan berpengaruh positif pada kepatuhan wajib pajak orang pribadi. Setelah dilakukan pengujian, hasil penelitian menujukkan bahwa $\beta_{1}=0,593$ dengan nilai tingkat signifikansi 0,000 yang lebih kecil dari taraf nyata 0,05 . Dengan demikian dapat diartikan reformasi administrasi perpajakan berpengaruh positif dan signifikan pada kepatuhan wajib pajak orang pribadi, maka hipotesis pertama $\left(\mathrm{H}_{1}\right)$ dalam penelitian ini diterima.

Hasil penelitian memiliki arti bahwa terdapat pengaruh positif signifikan antara reformasi administrasi perpajakan $\left(\mathrm{X}_{1}\right)$ pada kepatuhan wajib pajak orang pribadi (Y). Arah positif tersebut memiliki arti bahwa reformasi administrasi perpajakan seperti restrukturisasi organisasi yang berdasarkan fungsi dengan adanya Account Representative memudahkan wajib pajak orang pribadi dalam menyelesaikan kegiatan perpajakannya sehingga mampu meningkatkan kepatuhan wajib pajak, proses bisnis dan teknologi informasi serta komunikasi (e-SPT, $e$ billing, e-registration dan e-filling) mampu memberikan kemudahan dan menghemat waktu bagi wajib pajak dalam memenuhi kegiatan perpajakannya sehingga pelayanan tersebut mampu meningkatkan kepatuhan wajib pajak, 
manajemen sumber daya manusia yang membentuk tenaga kerja yang profesional dapat memberikan solusi bagi setiap pemasalahan wajib pajak sehingga wajib pajak akan merasa puas dan berdampak pada peningkatan kepatuhan wajib pajak, serta penerapan good governance dimana menunjukkan bahwa aparatur pajak yang bersih, adil, dan jujur dalam pelaksanaannya memberikan kepuasan pada wajib pajak orang pribadi sehingga meningkatkan kepatuhan wajib pajak.

Hasil penelitian ini sejalan dengan penelitian yang dilakukan oleh (Sugi \& Lely, 2017) yang menunjukkan bahwa reformasi administrasi perpajakan berpengaruh positif pada kepatuhan wajib pajak orang pribadi di KPP Pratama Gianyar.

Hipotesis kedua $\left(\mathrm{H}_{2}\right)$ menyatakan bahwa tax amnesty berpengaruh positif pada kepatuhan wajib pajak orang pribadi dalam penelitian ini ditolak. Setelah dilakukan pengujian, hasil penelitian menunjukkan bahwa $\beta_{2}=-0,146$ dengan nilai tingkat signifikansi sebesar 0,654 yang lebih besar dari taraf nyata 0,05 . Dengan demikian dapat diartikan tax amnesty tidak berpengaruh pada kepatuhan wajib pajak orang pribadi. Hal ini dapat dijelaskan bahwa pemerintah telah mengeluarkan kebijakan tax amnesty bagi masyarakat khususnya wajib pajak, dimana pemerintah melaksanakan kebijakan pengampunan perpajakan dengan harapan kepatuhan wajib pajak dapat ditingkatkan yang nantinya berpengaruh terhadap pendapatan negara untuk kesejahteraan masyarakat. Namun, jika dilihat dari pendapat wajib pajak mereka masih kurang memahami pentingnya atau fungsi dari kebijakan tax amnesty itu sendiri karena dari jawaban yang diberikan 
responden masih ragu-ragu akan kebijakan pemerintah serta administrasi perpajakan dan masih belum memahami betul kebijakan tersebut. Hal ini dapat terjadi saat kondisi tax amnesty rendah atau tax amnesty sedang tidak dilaksanakan.

Hasil penelitian ini sejalan dengan penelitian oleh (Suyanto \& Putri, 2017) yang menyatakan tax amensty tidak berpengaruh terhadap kepatuhan wajib pajak orang pribadi.

Hipotesis ketiga $\left(\mathrm{H}_{3}\right)$ menyatakan bahwa preferensi risiko memperlemah hubungan antara reformasi administrasi perpajakan pada kepatuhan wajib pajak orang pribadi. Setelah dilakukan pengujian, hasil penelitian ini menunjukkan bahwa $\beta_{1}=-0,013$ dengan nilai tingkat signifikansi sebesar 0,013 yang nilainya lebih kecil dari taraf nyata 0,05. Dengan demikian dapat diartikan bahwa preferensi risiko dapat memperlemah pengaruh reformasi administrasi perpajakan pada kepatuhan wajib pajak orang pribadi.

Data tersebut menunjukkan bahwa $\mathrm{H}_{3}$ diterima dan preferensi risiko dapat memperlemah pengaruh reformasi administrasi perpajakan pada kepatuhan wajib pajak. Hal ini berarti bahwa hubungan antara reformasi administrasi perpajakan dengan kepatuhan wajib pajak orang pribadi yang awalnya positif signifikan setelah ditambahkan variabel preferensi risiko sebagai moderasi menjadi melemah. Hal ini sesuai dengan teori prospek, dimana preferensi seseorang terhadap risiko akan mempengaruhi keputusan wajib pajak tersebut. Risiko yang dipertimbangkan meliputi risiko keuangan, risiko kesehatan dan risiko pekerjaan. 
Walaupun persepsi wajib pajak tentang reformasi administrasi perpajakan baik tetapi wajib pajak memiliki preferensi risiko yang tinggi, wajib pajak tersebut bisa tidak patuh dengan kewajiban perpajakannya.

Hipotesis keempat $\left(\mathrm{H}_{4}\right)$ menyatakan bahwa preferensi risiko memperkuat hubungan antara tax amnesty dengan kepatuhan wajib pajak orang pribadi. Setelah dilakukan pengujian, hasil penelitian menunjukkan bahwa $\beta_{1}=0,025$ dengan nilai tingkat signifikansi sebesar 0,018 yang lebih kecil dari taraf nyata 0,05. Dengan demikian dapat diartikan preferensi risiko memperkuat hubungan tax amnesty pada kepatuhan wajib pajak orang pribadi. Data tersebut menunjukkan bahwa $\mathrm{H}_{4}$ diterima. Hal ini berarti bahwa preferensi risiko dapat memperkuat pengaruh negatif dari tax amnesty pada kepatuhan wajib pajak orang pribadi. Hal ini disebabkan karena keragu-raguan wajib pajak akan kebijakan pemerintah dan administrasi perpajakan tentang tax amnesty, diperkuat dengan risiko-risiko yang akan dihadapi seperti risiko keuangan, risiko kesehatan, risiko pekerjaan, risiko sosial dan risiko keselamatan. Kepatuhan wajib pajak akan terganggu pada saat kondisi tax amnesty rendah dan ditambah dengan preferensi risiko dari wajib pajak, hal ini sesuai dengan teori prospek dimana dikatakan bahwa preferensi terhadap risiko yang dihadapi wajib pajak akan mempengaruhi keputusannya dalam melaksanakan perpajakan.

\section{SIMPULAN}

Reformasi administrasi perpajakan berpengaruh positif pada kepatuhan wajib pajak orang pribadi di Kantor Pelayanan Pajak Pratama Badung Utara yang 
memiliki arti bahwa reformasi administrasi perpajakan dapat meningkatkan kepatuhan wajib pajak orang pribadi.

Tax amnesty tidak berpengaruh pada kepatuhan wajib pajak orang pribadi di Kantor Pelayanan Pajak Pratama Badung Utara yang memiliki arti bahwa ada atau tidaknya tax amnesty tidak mempengaruhi kepatuhan wajib pajak orang pribadi.

Preferensi risiko (moderasi semu) memperlemah hubungan reformasi administrasi perpajakan pada kepatuhan wajib pajak orang pribadi di Kantor Pelayanan Pajak Pratama Badung Utara yang memiliki arti bahwa preferensi risiko memperlemah pengaruh positif dari reformasi administrasi perpajakan pada kepatuhan wajib pajak orang pribadi.

Preferensi risiko (moderasi semu) memperkuat hubungan tax amnesty pada kepatuhan wajib pajak orang pribadi di Kantor Pelayanan Pajak Pratama Badung Utara yang memiliki arti bahwa preferensi risiko memperkuat pengaruh negatif dari tax amnesty pada kepatuhan wajib pajak orang pribadi.

KPP Pratama Badung Utara diharapkan lebih aktif dalam melakukan penyuluhan dan penyebaran informasi kepada masyarakat, mengenai sistem administrasi perpajakan yang telah direformasi seperti pembayaran pajak secara online (internet banking, e-billing dan ATM). Reformasi ini bertujuan untuk memudahkan wajib pajak karena dapat dilakukan dengan cepat dan kapan saja. Wajib pajak dapat memanfaatkan sistem tersebut dengan lebih baik lagi dalam melaksanakan kewajiban perpajakannya yang nanti memberikan dampak positif pada peningkatan kepatuhan wajib pajak. KPP Pratama Badung Utara juga 
diharapkan lebih mensosialisasikan tentang kebijakan tax amnesty dan tata cara perpajakan sehingga dapat meningkatkan kepatuhan wajib pajak orang pribadi.

Wajib pajak orang pribadi sebaiknya lebih paham akan kewajiban sebagai warga negara dalam melakukan kewajiban perpajakannya yang nantinya akan berguna untuk kelangsungan hidup negara dan membantu pembangunan negara. Selain aparatur pajak yang gencar dalam mensosialisasikan peraturan perpajakan, wajib pajak juga sebaiknya ikut aktif dalam mencari tahu tentang kebijakan pemerintah seperti kebijakan tax amnesty dan tata cara pelaksanaan kewajiban perpajakan. Untuk wajib pajak yang memiliki investasi yang berisiko, mengalami kebangkrutan dan memiliki pekerjaan yang tidak tetap sebaiknya merencanakan kewajiban perpajakannya dengan bijak dan berkonsultasi pada petugas perpajakan, agar nantinya hal tersebut dapat diberikan solusi oleh pertugas pajak sesuai dengan Undang-undang yang berlaku.

\section{REFERENSI}

Adhistyastuti, F., Afifudin, \& Mawardi, C. M. (2016). Pengaruh Modernisasi Administrasi Perpajakan dan Kesadaran Wajib Pajak Terhadap Kepatuhan Wajib Pajak Orang Pribadi di Kantor Pelayanan Pajak Pratama Batu. Jurnal Ekonomi Akuntansi Universitas Islam Malang, 54-66.

Alabede, J. O., Ariffin, Z. B. Z., \& Idris, M. K. (2011). Public Governance Quality and Tax Compliance Behavior in Nigeria: The Moderating Role of Financial Condition and Risk Preference. Journal of Social and Environmental Accounting,5(1), 3-24.

Andriyani, S. (2016). Faktor-faktor yang Berpengaruh Terhadap Kepatuhan Wajib Pajak dengan Preferensi Risiko Sebagai Pemoderasi (Studi Kasus pada Wajib Pajak Badan Hotel di DIY). Jurnal Ekonomi Universitas Muhammadiyah Yogyakarta, 1-21. 
Ariesta, R. P., \& Latifah, L. (2017).Pengaruh Kesadaran Wajib Pajak, Sanksi Perpajakan, Sistem Administrasi Perpajakan Modern, Pengetahuan Korupsi, dan Tax Amnesty Terhadap Kepatuhan Wajib Pajak. Jurnal Ekonomi Universitas Negeri Semarang, 1(2), 173-187.

Aryobimo, P. T., \& Cahyonowati, N. (2012). Pengaruh Persepsi Wajib Pajak tentang Kualitas Pelayanan Fiskus terhadap Kepatuhan Wajib Pajak dengan Kondisi Keuangan Wajib Pajak dan Preferensi Risiko sebagai Variabel Moderating ( Studi Empiris terhadap Wajib Pajak Orang Pribadi di Kota Semarang ). Jurnal Akuntansi Universitas Diponogoro, 1, 1-12.

Ayu, V., \& Sari, P. (2017). Pengaruh Tax Amnesty, Pengetahuan Perpajakan, dan Pelayanan Fiskus Terhadap Kepatuhan Wajib Pajak. Jurnal Ekonomi Sekolah Tinggi Ilmu Ekonomi Indonesia ( STIESIA ) Surabaya.

Aziz, M. A. A., Ask, N. S., \& Afifudin. (2014). Pengaruh Pemahaman Peraturan Perpajakan Terhadap Kepatuhan Wajib Pajak dengan Preferensi Risiko Sebagai Variabel Moderating. Jurnal Fakultas Ekonomi Universitas Islam Malang, 26-36.

Enni, S., \& Musfialdy. (2016). The Effect of Taxpayer Awareness, Tax Socialization, Tax Penalties, Compliance Cost at Taxpayer Compliance with Service Quality as Mediating Variable. Procedia - Social and Behavioral Sciences, 219, 682-687.

Frey, B. S., \& Torgler, B. (2007). Tax Morale and Conditional Cooperation. Journal of Comparative Economics, 35(1), 136-159.

Harmawati, N. K. A., \& Yadnyana, I. K. (2016). Pengaruh Pemahaman Perpajakan, Kualitas Pelayanan, Ketegasan Sanksi Pajak dan Pemeriksaan Pajak pada Kepatuhan Wajib Pajak PBB-P2 dengan Tingkat Pendidikan Sebagai Pemoderasi. E-Jurnal Ekonomi Dan Bisnis Universitas Udayana, 6, 1513-1542.

Hatta, U. B., Muhammad, U. M., \& Solok, Y. (2016). The Impact of Tax Knowledge on Tax Compliance Case Study in Kota Padang, Indonesia Akademia Baru, 2(1), 22-30.

Herbert, J., Sondakh, J. J., \& Warongan, J. (2017). Pengaruh Pemahaman Wajib Pajak, Kesadaran Pajak, Sanksi Perpajakan dan Pelayanan Fiskus Terhadap Kepatuhan Wajib Pajak. Jurnal Ekonomi Universitas Sam Ratulangi, 5(2), 443-453. 
Husnurrosyidah. (2016). Pengaruh Tax Amnesty Dan Sanksi Pajak Terhadap Kepatuhan Pajak di Bmt Se-Keresidenan Pati. Jurnal Ekonomi Syariah, 4, 211-226.

Ibrahim, M. A., Myrna, R., Irawati, I., \& Kristiadi, J. B. (2017). A Systematic Literature Review on Tax Amnesty in 9 Asian Countries. Journal of Economics and Financial Issues, 7(3), 220-225.

Irawan, H. (2013). Pengaruh Sistem Administrasi Perpajakan Modern Terhadap Kepatuhan Wajib Pajak Pada Kantor Pelayanan Pajak Madya Palembang. Jurnal Akuntansi STIE MDP, (2), 1-9.

Ismawati, E. (2017). Pengaruh Pemahaman Peraturan Perpajakan, Kualitas Pelayanan Fiskus, Sanksi Pajak, dan Tax Amnesty Terhadap Kepatuhan Wajib Pajak dengan Preferensi Risiko Sebagai Variabel Moderasi ( Studi pada KPP Pratama Kota Kudus). Skripsi. Fakultas Ekonomi dan Bisnis Islam Negeri Surakarta.

Julianti, M. (2014). Analisa Faktor - Faktor yang Mempengaruhi Kepatuhan Wajib Pajak Orang Pribadi untuk Membayar Pajak dengan Kondisi Keuangan dan Preferensi Risiko Wajib Pajak Sebagai Variabel Moderating( Studi Kasus pada Wajib Pajak yang Terdaftar di KPP Pratama Candisari Semarang ). Jurnal Ekonomi Universitas Diponogoro, 3(2005), 1-15.

Lestari, R., Hamid, D., \& Faisal, M. (2013). Pengaruh Modernisasi Sistem Administrasi Perpajakan Terhadap Tingkat Kepatuhan Wajib Pajak pada Kantor Pelayanan Pajak Pratama Batu.Jurnal Administrasi Bisnis Universitas Brawijaya.

Mahangila, Deogratius Ng'winula. (2017). The Impact of Tax Compliance Costs on Tax Compliance Behavior. Journal of Tax Administration, 3(1), 57-81.

Mahestyanti, P., Juanda, B., \& Anggraeni, L. (2018). The Determinants of Tax Compliance in Tax Amnesty Programs : Experimental Approach. Etikonomi : Jurnal Ekonomi,17(1), 93-110.

Marandau, Edward E., Mbekomize, Christian J., Ifezue, Alexander N. (2015). Determinants of Tax Compliance: A Review of Factors and Conceptualization. International Journal of Economics and Finance , 7(9), 207-218.

Mohamad, T. H., Hartati, T., \& Yusuf, N. (2015). Pengaruh Tingkat Pendidikan Wajib Pajak Orang Pribadi Terhadap Kepatuhan Membayar Pajak pada Kantor Pelayanan Pajak Pratama Gorontalo, 3(1), 1-21. 
Murat, D. (2014). Factors Affecting Tax Compliance of Taxpayers: The Role of Tax Officer The Case of Istanbul and Canakkale *. Journal of Business and Economics Research, 5(2), 19-31.

Nar, Mehmet. (2015). The Effect of Behavioral Economics on Tax Amnesty. International Journal of Economics and Financial Issues, 5(2), 580-589.

Novelina, H. (2017). Pengaruh Modernisasi Sistem Administrasi Perpajakan Terhadap Kepatuhan Wajib Pajak pada KPP Kanwil DJP Jatim I dan Jatim II.Jurnal Akuntansi STIE Perbanas Surabaya.

Nurlaela, S., Mursito, B., Hadi, S., \& Hendra, K. (2017). Effect Of Understanding, Knowledge And Tax Amnestytopay Tax Compliance With Individual Parliament Regionalin Indonesia. Account and Financial Management Journal, 2(3), 2456-3374.

Putri, R. L. (2015). Pengaruh Motivasi Membayar Pajak dan Tingkat Pendidikan Terhadap Kepatuhan Wajib Pajak Orang Pribadi. Jurnal Akuntansi Universitas Negeri Yogyakarta, (2), 1-12.

Rahayu, N. (2017).Pengaruh Pengetahuan Perpajakan, Ketegasan Sanksi, dan Tax Amnesty Terhadap Kepatuhan Wajib Pajak. Jurnal Akuntansi Dewantara, 1(1), 15-30.

Rorong, N. E., Kalangi, L., \& Runta, T. (2017). Pengaruh Kebijakan Tax Amnesty, Kesadaran Wajib Pajak dan Sanksi Pajak Terhadap Kepatuhan Wajib Pajak Orang Pribadi di KPP Pratama Manado. Jurnal Riset Akuntansi Going Concern, 12(2), 175-187.

Sari, R. I., \& Nuswantara, D. A. (2017). The Influence of Tax Amnesty Benefit Perception to Taxpayer Compliance. Jurnal Dinamika Akuntansi, 9(2), 176183.

Savitri, E. (2015). The Effect of Tax Socialization, Tax Knowledge, Expediency of Tax ID Number and Service Quality on Taxpayers Compliance With Taxpayers Awareness as Mediating Variables. Procedia - Social and Behavioral Sciences, 211(September), 163-169.

Sayekti, F., \& Wijayanti, L. E. (2018). The Infulence of Moderenization Tax to The Taxpayer's Compliance : A Case Study In Directorate General Tax Yogyakarta Office. The International Journal of Social Science, Education and Human Science UTY, 1(1). 
Sugi Astana, I. W., \& Lely Aryani Merkusiwati, N. K. (2017). Pengaruh Sistem Administrasi Perpajakan Modern dan Kesadaran Wajib Pajak Terhadap Kepatuhan Wajib Pajak Orang Pribadi.E-Jurnal Akuntansi Universitas Udayana, 18, 818-846.

Suyanto \& Putri, Ika Septiani. (2017). Pengaruh Persepsi Wajib Pajak Tentang Kebijakan Tax Amnesty (Pengampunan Pajak), dan Motivasi Membayar Pajak Terhadap Kepatuhan Perpajakan. Jurnal Akuntansi Universitas Sarjanawiyata Tamansiswa Yogyakarta, 5, 49-56.

Waluyo. (2017). Tax Amnesty and Tax Administration System: An Empirical Study in Indonesia. European Research Studies Journal, XX(4), 548-556.

Wirawan, I. B. N. A. P., \& Noviari, N. (2017).Pengaruh Penerapan Kebijakan Tax Amnesty dan Sanksi Perpajakan Terhadap Kepatuhan Wajib Pajak Orang Pribadi. E-Jurnal Akuntansi Universitas Udayana, 21, 2165-2194. 